\title{
Prospection of Indigenous Yeasts from Uruguayan Tannat Vineyards with a View to Their Oenological Applications
}

\section{Guillermo Morera}

Universidad de la Republica Uruguay

\section{Stefani de Ovalle}

Universidad de la Republica Uruguay

Paula Gonzalez -Pombo ( $\nabla$ pgonzale@fq.edu.uy )

Universidad de la Republica Uruguay https://orcid.org/0000-0002-5698-3590

\section{Research Article}

Keywords: non-Saccharomyces, native yeasts, strain characterization, Tannat grapes, wine, fermentation

Posted Date: March 2nd, 2022

DOI: https://doi.org/10.21203/rs.3.rs-1373501/v1

License: (c) (i) This work is licensed under a Creative Commons Attribution 4.0 International License. Read Full License 


\section{Abstract}

Prospection of yeasts from oenological environments can provide knowledge of new native strains that are capable of ferment must and positively influence the composition and sensory characteristics of the wine. This work is addressed to the biotechnological characterization of indigenous yeast of Tannat must, an emblematic and widespread vineyard of Uruguay. Fifty-three yeast strains were morphologically characterized and further identified by amplification and sequencing of ITS and D1-D2 regions, grouping into a total of fifteen species. A representative strain of each species was selected and evaluated for its technological traits. In presence of ethanol (6 to $16 \% \mathrm{v} / \mathrm{v})$ and SO2 (40 mg/L), native Saccharomyces cerevisiae T19-3FS presented the best growth rates and minors lag phase. Of the non-Saccharomyces strains, $S$. bacillaris T19-3MS stood out for its behavior in vinification conditions, more closely related with Saccharomyces strains.

S. cerevisiae T19-3FS, S. bacillaris T19-3MS, S. diversa T19-1FS and P. terricola T19-1FN conducted a successful fermentation process reaching final ethanol concentration $\geq 10 \% \mathrm{v} / \mathrm{v}$, and showed $\mathrm{K}+\mathrm{R}$ phenotype, highlighting its potential use in pure starter cultures for the production of finished wines. It also notes that $S$. diversa T19-1FS exhibits BGL activity making it interesting to explore its possible activity onto non-volatile glycosides during fermentation, to enhance aromatic compounds. Regarding the rest of the NS yeast studied, they could be good candidates for use in mixed-fermentations with Saccharomyces.

\section{Introduction}

Winemaking is an ancient technology improved for about 7000 years, which involves ecological and biochemical processes. The quality and aroma complexity of wines depends on several factors such as microclimate, grape variety, agronomics techniques, and mainly on yeasts that lead to biotransformation of grape juice in wine. Saccharomyces cerevisiae dominates the course of the fermentation and plays an essential role in the completion of alcoholic fermentation. Many other indigenous non-Saccharomyces (NS) yeasts participate in the winemaking process during the early stages because they are usually surpassed by $S$. cerevisiae due to their limited tolerance to ethanol and sulfites. Nevertheless, NS yeasts can have a great impact due to relevant enzymatic activities and production of metabolites of oenological significance that influence the organoleptic and sensory properties of wines(Cordero-Bueso et al. 2013; López et al. 2015).

In more recent years there has been a solid discussion among winemakers and scientists about the 'standardization' of the wines due to the use of the same cultures in many different regions, resulting in wines will lack complexity, typicity, and distinction (Binati et al. 2019). So, the selection of suitable yeast strains that have evolved in vineyards, and are well adapted to microclimate is a step of crucial significance to their biotechnological application and to distinguish regional characters (Maro et al. 2007; Suárez-Lepe and Morata 2012; Šuranská et al. 2016; Padilla et al. 2016). The specific environmental conditions must play a role in determining what species can survive and grow during the fermentation process. Yeasts selected from the natural microbiota must exhibit particular physiological traits to resist hostile environments conditions, such as acidic $\mathrm{pH}(3.0-4.0)$, high concentration of ethanol and sugars (mostly glucose and fructose), low oxygen levels close to the end of fermentation, and antiseptic concentrations of 
sulfur dioxide $\left(\mathrm{SO}_{2}\right)$. A useful parameter for the study of how the different strains are affected by these conditions is to determine their tolerance under them (Ortiz-Barrera et al. 2015; Vigentini et al. 2017). In this sense, the sought properties are related to a good development at $\mathrm{pH} 3.5$, rapid adaptation to the medium, production of some enzymes activities or metabolites that will influence the quality of the wine and be able to survive in an environment with other competitive yeasts (Eder et al. 2017).

Uruguayan oenology is recognized in the world for its Tannat wines, the most widespread variety, and has become the emblematic grape of the country for its unique and velvety flavor and its innumerable international awards. Although some information is available about volatile constituents and sensory attributes of Tannat there is so much to explore about the yeast population present on these grapes (Boido et al. 2003; Fariña et al. 2015).

This work is addressed to the biotechnological characterization of fifty-three indigenous yeast of Tannat must of Bodega Garzón, an exclusive location with the influence of the Atlantic Ocean on the vineyards. This experimental approach will give a clear understanding of the limitations and potential that each strain could offer for a successive application in winemaking. The strains were physiologically, biochemically, and oenologically characterized, in order to identify the strains suitable for the use as sole inoculum or potential to be used in mixed starters for the production of low alcohol wine.

\section{Materials And Methods}

\section{Grape sampling and yeast isolation.}

Indigenous yeast strains were isolated from grape berries skin and spontaneously fermented musts at different stages of the fermentation process. Grapes were collected in Tannat vineyards of Bodega Garzón, a winery located in the East region of Uruguay, department of Maldonado. Ten healthy and undamaged sample grape clusters were randomly and aseptically collected from each 40 vines lines before the 2019 harvest. Grapes in sterile plastic bags were transported to the lab in cold conditions and stored in the freezer at $-20^{\circ} \mathrm{C}$.

The grape berries skin isolation was made from manual grinding following Pallmann et al. (2001), selecting 10 grapes randomly per vineyard line and placing them in a sterile mortar. After ten minutes, an aliquot of juice was separated and serial dilutions were made to obtain plates with 30-300 colonies. Must samples diluted were spread on the surface on Wallerstein Laboratory Nutrient (WLN) medium (AcumediaR Lab, England) and incubated for $48 \mathrm{~h}$ at $26^{\circ} \mathrm{C}$ to presumptively discriminate colony morphology and color (Chavan et al. 2009; Pallmann et al. 2001). In addition, isolated strains were spread onto lysine agar (LA) (Oxoid Unipath Ltd, Hampshire, England) to assess the NS yeasts (Maio et al. 2012).

For spontaneous fermentation, grapes randomly taken from each vineyard line were macerated as described in Francesca et al. (2010). The must obtain was aliquoted and cultivated in falcon tubes with airlock valves and supplemented with amino acids solution to a final concentration of $(\mathrm{mg} / \mathrm{L})$ : proline 20.5 , L-glutamine 16.9, L-arginine 1.25, L-tryptophan 6, L-alanine 4.9, L-glutamic acid 4, L-serine 2.6, L-threonine 2.6, L-leucine 1.6, L-aspartic acid 1.5, L-valine 1.5, L-phenylalanine 1.3, L-isoleucine 1.1, L-histidine 1.1, L-methionine 1.1, L- 
tyrosine 0.6 , L-glycine 0.6 , L-lysine 0.6 , L-cysteine 0.4 . The must sample were taken aseptically every $48 \mathrm{hs}$ and appropriate dilutions in saline solution $(0.9 \% \mathrm{w} / \mathrm{v})$ were spread on plates in WLN medium and incubated $48 \mathrm{~h}$ at $26^{\circ} \mathrm{C}$ as also in LA medium. Colonies were isolated and purified on YPD agar plates [1\% $(\mathrm{w} / \mathrm{v})$ yeast extract, $2 \%(\mathrm{w} / \mathrm{v})$ peptone, $2 \%(\mathrm{w} / \mathrm{v})$ dextrose and $2 \%(\mathrm{w} / \mathrm{v})$ agar] and analyzed its cell shape under microscope. Pure isolates were stored in a liquid YPD medium with $20 \% \mathrm{v} / \mathrm{v}$ glycerol in the freezer at $-70^{\circ} \mathrm{C}$. Fermentations were monitored by a refractometer until the decline of degrees Brix ( $\left.{ }^{\circ} \mathrm{B}\right)$ stopped.

\section{DNA extraction and molecular identification}

DNA extractions were carried out using the Quick-DNA kit (Zymo Research) following the factory instructions and from cell lysates prepared as indicated below. One colony was taken per culture with sterile toothpicks and suspended in $10 \mu \mathrm{L}$ of $\mathrm{mQ}$ water. Then 25 units of Lyticase (Merck KgaA, Germany) were added and incubated at $30^{\circ} \mathrm{C}$ for 10 minutes. Finally, tubes were placed in a freezer at $-80^{\circ} \mathrm{C}$ for 10 minutes. PCR reactions were performed alternately for the Internal Transcribed Spacer (ITS) or the D1-D2 domain of the Large Subunit Ribosomal DNA. PCR was performed in $50 \mu \mathrm{L}$ of a reaction mixture containing $5 \mu \mathrm{L}$ of Taq buffer (10X) (NZYTech, Portugal), 0.05mM of dNTPs (Qiagen, Germany), $0.2 \mu \mathrm{M}$ of ITS1 (Macrogen Inc. South Korea) (19-mer 5-TCC GTA GGT GAA CCT GCG G-3) and ITS4 (Macrogen Inc. South Korea) (21-mer 5TCC TCC GCT TTA TTG ATA TGC-3) (Zott et al. 2008), 2.5 units of Taq DNA Polymerase (Qiagen, Germany) and $5 \mu \mathrm{L}$ of cell lysate. Thermocycler (Eppendorf) was configured as initial denaturation of $94^{\circ} \mathrm{C} 3 \mathrm{~min}, 30$ successive cycles of $1 \mathrm{~min}$ at $94^{\circ} \mathrm{C}, 45 \mathrm{sec}$ at $60^{\circ} \mathrm{C}$, and $1 \mathrm{~min}$ at $72^{\circ} \mathrm{C}$, with a final extension phase of $5 \mathrm{~min}$ at $72^{\circ} \mathrm{C}$. In the case of the D1/D2 region, PCR reactions were performed as follows: $170 \mathrm{ng}$ of genomic DNA, $5 \mu \mathrm{L}$ Taq buffer (10X), $0.2 \mu \mathrm{M}$ of LROR (Macrogen, Inc. South Korea) (17-mer 5-ACCCGCTGAACTTAAGC-3) and LR3 (Macrogen, Inc. South Korea) (17-mer 5-CCGTGTTTCAAGACGGG-3) (Flakus et al. 2019), 0.05 mM of dNTPs $1.50 \mathrm{mM}$ of $\mathrm{MgCl}_{2}, 2.5$ units of Taq DNA polymerase. PCR protocol was performed as follows: initial denaturation of $2 \mathrm{~min}$ at $95^{\circ} \mathrm{C}, 30$ successive cycles: $1 \mathrm{~min}$ at $94^{\circ} \mathrm{C}, 2 \mathrm{~min}$ at $56^{\circ} \mathrm{C}$, and $2 \mathrm{~min}$ at $72^{\circ}$ $\mathrm{C}$ with a final phase of extension at $10 \mathrm{~min}$ at $72^{\circ} \mathrm{C}$. PCR products were analyzed in a $1 \%(\mathrm{w} / \mathrm{v})$ agarose gel (with $1 \mu \mathrm{L}$ SYBR Safe Invitrogen, United States, or Gel Green Biotium, United States), and observed under UV light. The accurate sizes of the products were estimated using the GeneRuler DNA Ladder Mix marker (Thermo). Finally, PCR products were sent to Macrogen (Seoul, Korea) for standard sequence service. The sequences were manually corrected with Bioedit V.7.0.5.3 software and compared with representative sequences of the GenBank database, using the BLAST method (http://ncbi.nlm.nih.gov/BLAST). Sequences with $98 \%$ nucleotide identity or higher for ITS (Eder et al. 2017) and 99\% or higher in D1-D2 (Nasanit et al. 2016), were considered the same species.

\section{Evaluation of biotechnological traits}

Fast screening of yeast pure isolates in presence of ethanol or sulfur dioxide $\left(\mathrm{SO}_{2}\right)$ were performed on ELISA microplates for evaluating the fermentative yield in these conditions. In each case, $25 \times 10^{7}$ cells were added to $200 \mu$ l of YPD (pH 3.5), with a final ethanol concentration of 6,11 and $16 \%(v / v)$ or sodium metabisulfite $\mathrm{SO}_{2}(40 \mathrm{mg} / \mathrm{L})$. Corresponding control without ethanol or sodium metabisulfite addition was carried out and all the assays were done in triplicates. The S. cerevisiae T73-2, kindly provided by Dr. Ramón González from 
ICVV Logroño, Spain was use as reference strain (Puig et al. 1998). Cell growth for 24 hours was measured on an Infinite ${ }^{\circledR}$ M200 PRO Fluormeter, monitoring optical density at $600 \mathrm{~nm}$ (OD600).

The specific growth rate $\mu\left(h^{-1}\right)$ for each strain was estimated as expressed in Madigan et al. (2005): $\mathrm{N}=\mathrm{N}_{0} 2^{\text {ut }}$

Where: $\mathrm{N}$ is the final number of cells or photometric units (OD600), $\mathrm{N}_{0}$ is the initial number of cells or photometric units (OD600), $\mu$ corresponds to the specific growth rate, $t$ is the time duration of the exponential phase. The duration of the lag phase (h) was estimated according to the authors Madigan et al. (2005) and Tikka et al. (2013). Principal Component Analysis (PCA) was performed in Infostat (Di Rienzo et al. 2010). In addition, percentages of growth inhibition intrinsic for each strain were calculated comparing the OD600 (at $24 \mathrm{~h}$ ) with each yeast control assay in YPD at pH 3.0 without ethanol and sulfur dioxide $\left(\mathrm{SO}_{2}\right)$.

\section{Fermentation and growth kinetics}

Fermentations were prepared using the must from Tannat grapes processed according to methods previously described with modifications (Capece et al. 2016; Francesca et al. 2010). The must prepared from 2019 Tannat vintage pressing grapes, was pasteurized performing a short cycle of temperature increase to $105^{\circ} \mathrm{C}$ and subsequent gradual decrease. The characteristics of the pasteurized must be as follows: $252.97 \mathrm{~g} / \mathrm{L}$ of sugars (128.88 g/L glucose, $124.09 \mathrm{~g} / \mathrm{L}$ fructose), $150 \mathrm{mg} \mathrm{N} / \mathrm{L}$ of yeast assimilable nitrogen (YAN) (THIAZOTE $®$ PH - LAFFORT $\left.{ }^{\circledR}\right), \mathrm{pH} 3.75,22.7^{\circ} \mathrm{Brix}\left({ }^{\circ} \mathrm{B}\right)$, and $1.1 \mathrm{~g} / \mathrm{L}$ density. Wine strains were precultured in Erlenmeyer flasks filled up to $10 \%$ of volume with pasteurized must, in overnight agitation (150 $\mathrm{rpm}$ ) at $28^{\circ} \mathrm{C}$. Cultures were subsequently inoculated with about $2 \times 10^{6} \mathrm{cell} / \mathrm{mL}$ in Erlenmeyer flasks containing $50 \mathrm{~mL}$ of pasteurized grape juice. Fermentation assays were carried out in duplicates at $26^{\circ} \mathrm{C}$ for 14 days in semi-anaerobic conditions. Fermentation with S. cerevisiae strain T73-2 was carried out, at the same conditions. Sterilized non-inoculated must be used as a control to assure the stability of the must during assay conditions. Samples were monitored daily by measuring weight loss ( $\mathrm{g}$ of $\mathrm{CO}_{2}$ released). Fermentative vigor $\left(\mathrm{CO}_{2}\right.$ released at $\left.72 \mathrm{~h}\right)$ and fermentative power (total $\mathrm{CO}_{2}$ released) were then estimated according to Capece et al. (2016).

\section{Metabolite analysis of Tannat must fermentation}

Fermentable sugars (fructose, glucose) and fermentation metabolites (acetic acid, ethanol and glycerol) were quantified by high-pressure liquid chromatography (HPLC Waters 510). A volume of $20 \mu \mathrm{L}$ of 1/10 diluted sample (or $1 / 100$ for must) was injected into ROA-Organic Acid H+ $8 \%$ (300 $\times 7.8 \mathrm{~mm}$ ) (Phenomenex) with a flow rate of $0.5 \mathrm{~mL} / \mathrm{min}$ of mobile phase $\left(1.5 \mathrm{mM}\right.$ of sulfuric acid) at $25^{\circ} \mathrm{C}$. The coupled detector used was the infrared (IR) (WATERS R401) and data processing was performed using Empower Software. All data is reported as the average of three replicates \pm standard deviation.

\section{Screening of $\beta$-glucosidase activity}


$\beta$-Glucosidase activity of each isolated strain was carried out using the esculin-glycerol-agar (EGA) method (González-Pombo et al. 2011; Pérez et al. 2011). EGA medium was prepared as follows: esculin $1 \mathrm{~g} / \mathrm{L}$, ferric chloride $0.6 \mathrm{~g} / \mathrm{L}$, peptone $2 \mathrm{~g} / \mathrm{L}$, yeast extract $50 \mathrm{~g} / \mathrm{L}$, glycerol $16 \mathrm{ml} / \mathrm{L}$, agar $20 \mathrm{~g} / \mathrm{L}$, adjust to $\mathrm{pH} 4.0$ and 5.0 . Strains were grown at $26^{\circ} \mathrm{C}$ and monitored for $96 \mathrm{~h}$. Kluyveromyces fragilis ATCC12424 strain and Saccharomyces cerevisiae M522 was used as the positive and negative control, respectively (Pérez et al. 2011). When a dark brown halo appeared around colonies on the plates, the results were considered positive.

\section{Killer phenotype}

The killer phenotype and sensitivity were analyzed following the diffusion agar technique on YPD with methylene blue (MB) $0.003 \%(\mathrm{w} / \mathrm{v})$ buffered at pH 4.6 with $0.1 \mathrm{M}$ citrate-phosphate buffer (Lopes and Sangorrín 2010). All isolates were tested for their killer activity (being Killer: K+ or No Killer: K-) against

sensitive reference strain (S. cerevisiae M522-K2 sensitive). Sensitivity (S) and resistance (R) were evaluated against a reference killer strain (S. cerevisiae T73-2 -K2 killer). Lawns were prepared inoculating $1 \times 10^{5}$ cells $/ \mathrm{ml}$ of each strain and plates were incubated for $72 \mathrm{~h}$ at $24^{\circ} \mathrm{C}$. When the streak of a spotted yeast isolated grew fringed with blue color, and surrounded by a clear zone of inhibition, the isolate was designated as "K+" and the lawn as "S". Otherwise, the isolate was "K-" and the lawn was "R." The assays were replicated three times and intensity of the inhibition zone was qualitatively assessed.

\section{Results And Discussion}

\section{Yeast strains, molecular identification, and morphological characterization}

Fifty-three yeast strains were identified through the isolation and sequencing analysis of ITS or D1-D2 regions and grouped in a total of fifteen species: ten corresponding to Phylum Ascomycota (Whittaker) and five corresponding to Phylum Basidiomycota (Whittaker ex Moore). Ascomycota yeasts species were: Saccharomyces cerevisiae, Hanseniaspora uvarum, Saturnispora diversa, Pichia terricola, Pichia occidentalis, Pichia cfr. fermentans, Candida parapsilosis, Starmerella bacillaris, Metschnikowia peoriensis and Metschnikowia pulcherrima. Basidiomycota species were Aureobasidium pullulans var. pullulans, Papiliotrema terrestris, Filobasidium magnum, Rhodotorula babjebae, and Sporidiobolus pararoseus (Table 1). Our records represent species of genera commonly found in the vineyard and are in agreement with previous reports where most of the NS strains are usually isolated from grape skins and must be in different stages of fermentation (Baffi et al. 2011; Sabate et al. 2002), whereas $S$. cerevisiae strain was isolated in advanced stages of fermentation (Bougreau et al. 2019; Jolly et al. 2006; Rainieri and Pretorius 2000).

Isolated yeasts exhibited specific colony morphology on WLN (Table 1), constituting a useful tool to preliminarily differentiate them (Pallmann et al. 2001; Romancino et al. 2008). The species Pichia terricola and Pichia occidentalis were difficult to differentiate by colony morphology, so the use of ITS region sequences was decisive to classify them. Pallmann et al. (2001) reported similar results for closely related species of M. pulcherrima. For Pichia cfr. fermentans strain, the ITS region showed mixed peaks and the D1- 
D2 region only allowed an approximate identification. Given this and its unique morphological features, we decided to keep it as a separate species, labeled Pichia cfr. fermentans. In this sense, it was reported that for Pichia species the use of intragenomic variations in the repetition of the rRNA gene carries controversial conclusions (Wu et al. 2016).

\section{Table 1}

\section{Evaluation of biotechnological traits}

Several criteria have been proposed for the selection of new yeast strains because not all yeast strains are appropriate in the specific conditions and winemaking process. In this work, a representative strain of each species was selected and evaluated for its technological traits: T19-7MN (Aureobasidium pullulans), T197MS (Filobasidium magnum), T19-2MN (Hanseniaspora uvarum), T19-6MN (Metschnikowia peoriensis), T19-10MS (Metschnikowia pulcherrima), T19-8MN (Papiliotrema terrestris), T19-10MN (Pichia cfr. fermentans), T19-2FN (Pichia occidentalis), T19-1FN (Pichia terricola), T19-5MN (Rhodotorula babjevae), T19-3FS (Saccharomyces cerevisiae), T19-1FS (Saturnispora diversa), T19-9MN (Sporidiobolus pararoseus) and T19-3MS (Starmerella bacillaris). Candida parapsilosis was excluded because of its role as a human pathogen (Silva et al. 2012). Sequences of each selected strain were submitted to GenBank, under the accession numbers: MZ707306, MZ707307, MZ707308, MZ707309, MZ707310, MZ735693, MZ735694, MZ73569, MZ735696, MZ836832, MZ836833, MZ836834, MZ836835, and MZ836836.

\section{Ethanol and metabisulfite strain behavior}

The ability of the yeasts to grow on limiting conditions and their usefulness in the industry is closely related to its fermentative behavior (Castilleja et al. 2017), Monitoring of OD600 by spectrometry allows determining quantitatively the suitability of the different strains to grow in stress conditions. Particularly the study of its adaptation, kinetic performance, and resistance in the presence of ethanol and metabisulfite are considered the main requirements to select strains for its use in winemaking (Castilleja et al. 2017; Zuzuarregui and del Olmo 2004). The influence of ethanol (6, 11, and 16\% v/v) and metabisulfite (40 mg/L) were studied and the behavior of the native strains was evaluated by determining the specific growth rate $(\mu)$ and length of the lag phase in comparison with the reference strain S. cerevisiae T73-2. The Basidiomycota yeast strains (Aureobasidium pullulans var. pullulans, Papiliotrema terrestris, Filobasidium magnum, Rhodotorula babjebae and Sporidiobolus pararoseus did not reach the exponential phase for any of the treatments with ethanol, metabisulfite, or even control. So, they were excluded from the subsequent stages of analysis. From Table 2, stands out the growth rate $(\mu)$ of native $S$. cerevisiae T19-3FS at $6 \%, 11 \%$, and $16 \% \mathrm{v} / \mathrm{v}$ of ethanol, which were very similar to that of the reference strain at the same conditions (Table 2). All NS strains showed lower growth rates values in ethanol at $6 \% \mathrm{v} / \mathrm{v}$ (from 0.07 to $0.13 \mathrm{~h}^{-1}$ ) and at $11 \%$ $\mathrm{v} / \mathrm{v}$ (from 0.02 to $0.09 \mathrm{~h}^{-1}$ ). These effects on NS were more noticeable at the highest concentration of $16 \%$ v/v, except for $S$. bacillaris T19-3MS that was capable of still growth $\left(0.06 \mathrm{~h}^{-1}\right)$. Both native and reference $S$. cerevisiae strains showed the same lag phases duration of $2 \mathrm{~h}$ at $6 \% \mathrm{v} / \mathrm{v}$ ethanol and $4 \mathrm{~h}$ for $11 \%$ and $16 \%$ v/v of ethanol, whereas NS strains showed longer lag phases (from 6 to $12 \mathrm{~h}$ ) at 6 and $11 \% \mathrm{v} / \mathrm{v}$. At $16 \% \mathrm{v} / \mathrm{v}$ of ethanol, no growth was observed, indicating that the presence of this metabolite at this concentration 
notoriously affected the adaptation of these yeasts to growth. Once again, S. bacillaris T19-3MS was the exception among the NS strains, growing at the highest ethanol concentration and three times slower than S. cerevisiae strains.

Considering that metabisulfite is frequently used in winemaking for the growth control of spoilage yeasts and bacteria, the characterization and adaptation of new yeasts in presence of this chemical is very important (Rojo-Bezares et al. 2007). At the concentration of metabisulfite $40 \mathrm{mg} / \mathrm{L}$, similar growth rates were found for $S$. bacillaris T19-3MS $\left(0.23 \mathrm{~h}^{-1}\right)$ and $S$. cerevisiae native and reference strains $\left(0.25 \mathrm{~h}^{-1}\right.$ and $0.26 \mathrm{~h}^{-1}$, respectively). Growth rates for the rest of the NS strains were notably lower, with values ranging from 0.09 to $0.16 \mathrm{~h}^{-1}$. The lag phase of $S$. bacillaris T19-3MS was twofold higher $\left(4 \pm 0 \mathrm{~h}^{-1}\right)$ compared to both $S$. cerevisiae strains $\left(2 \pm 0 \mathrm{~h}^{-1}\right)$.

\section{Table 2}

Principal Component Analysis (PCA) showed the effect of ethanol and $\mathrm{SO}_{2}$ in an integrative, multidimensional space (Fig. 1). The biplot explains $91.1 \%$ of the total variance, where the PC1 resumed $82.6 \%$ of the variance and allowed to discriminate strains of the right quadrant as the most skilled to growth (good rates) and minor lag phase for all tested conditions. Saccharomyces cerevisiae T19-3FS was grouped in the right quadrant with the reference strain, related with best growth rates and minors lag phase in all tested conditions. On the other hand, strains of the left quadrant showed the worst growth rates and long lag phase, where the majority of NS strains were located. S. bacillaris T19-3MS differs from the rest of NS strains and is located in the middle of the PCA plot; more related to the behavior of $S$. cerevisiae strains. $S$. bacillaris T19-3MS stands out for barely extending its lag phase, slightly decreasing its growth rate in the concentration of metabisulfite and ethanol present in vinification.

\section{Ethanol and metabisulfite strain inhibition}

It is well known that ethanol could modify and affect yeasts cell characteristics such as metabolism, growth, fluidity of the plasmatic membrane, among others (Castilleja et al. 2017; Maro et al. 2007; Pina et al. 2004). As is shown in Table 3, at $6 \% \mathrm{v} / \mathrm{v}$ of ethanol, in addition to $S$. cerevisiae strains, P. terrricola T19-1FN, S. bacillaris T19-3MS, and S. diversa T19-1FS were little affected, with inhibition percentages less than $10 \%$. The rest of the NS strains showed inhibition percentages in the range of $15-60 \%$. At $11 \% \mathrm{v} / \mathrm{v}$ of ethanol, $S$. cerevisiae strains were the most tolerant (no inhibition was detected). The majority of NS strains showed inhibition percentages in the range 55-81\% with exception of S. bacillaris T19-3MS that was barely affected (22 $\pm 8 \%$ inhibition). Our results agree with Englezos et al. (2015) and Tofalo et al. (2011); where $S$. bacillaris strains have been characterized as tolerant to ethanol. The more inhibitory condition was at $16 \%$ $\mathrm{v} / \mathrm{v}$ of ethanol, where all NS strains reached inhibition percentages greater than $80 \%$. Unlike reported by Eder et al. (2017) for indigenous Saccharomyces yeasts of Isabella must that were inhibited at an ethanol concentration of $10 \%$, we found that native $S$. cerevisiae T19-3FS was very tolerant at the highest ethanol concentration tested (16\%). These findings are following Cappello et al. (2004) and Senses-Ergul and Ozbas (2016), who reported indigenous $S$. cerevisiae strains as tolerant at a concentration of $14 \%$ ethanol. 
It has been widely established that metabisulfite is an antimicrobial, antioxidant, and reducing agent, which inhibits cell growth at concentrations of 20-50 mg/L (Corte et al. 2012; Englezos et al. 2015; Jolly et al. 2014). Regarding the presence of $40 \mathrm{mg} / \mathrm{L}$ of metabisulfite, all NS and S strains were slightly affected showing inhibition percentages in the range of $1-15 \%$. Previous work reported strains of Hanseniaspora uvarum species that could resist and grow yet in presence of $500 \mathrm{mg} / \mathrm{L}$ of $\mathrm{SO}_{2}$ (Hong and Park 2013). In the winemaking process, the NS strains could be inhibited not only due to the effect of $\mathrm{SO}_{2}$ stress but probably due to the combined toxicity with ethanol as established by Jolly et al. (2014).

\section{Table 3}

\section{Fermentation power and vigor}

The ability of different yeast strains to conduct and complete the fermentation of must was assessed by analyzing their performance in laboratory-scale following Capece et al. (2016). The study of the efficiency parameters will allow selecting those native strains that present fermentative abilities comparable to those normally used in the industry. Concerning the vigor and fermentative power of native yeast strains (Fig. 2), we encountered two principal groups of yields. The first one included S. cerevisiae T19-3FS, H. uvarum T192MN, S. bacillaris T19-3MS, and S. diversa T19-1FS, showing similar behavior to the reference strain $S$.

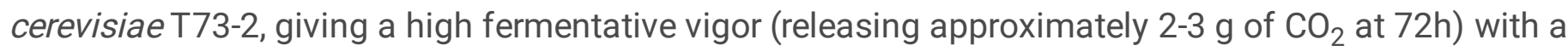
fermentative power of 6-7 $\mathrm{g}$ of $\mathrm{CO}_{2}$. These results demonstrated that these strains are capable of conducting fermentation on their own. The second group was composed of the rest of the strains, which showed lower fermentative vigor (releasing less than $1.3 \mathrm{~g}_{\text {of } \mathrm{CO}_{2}}$ at $72 \mathrm{~h}$ ) and low fermentative power with a total of $4-5 \mathrm{~g}$ of $\mathrm{CO}_{2}$. These yeasts could be interesting to produce wines with lower alcoholic content and evaluate its possible contribution to co-fermentation with Saccharomyces (Ciani and Comitini 2015; Maio et al. 2012; Sadoudi et al. 2012).

\section{Fermentation contribution of Saccharomyces and non-Saccharomyces yeasts}

To investigate fermentation activity of the selected strains, fermentation kinetics were monitored, and residual sugar, ethanol, and glycerol concentration were measured at the end of the fermentation (Table 4). As might be expected and in concordance with Fig. 2, the fermentation kinetics of the non-Saccharomyces yeasts were typically lower than the control strain, showing two groups: fermentative and non-fermentative strains (Table 4). Native T19-3FS, T193-MS, T19-1FS, and T19-2MN strains, were identified as fermentative strains as they consumed $>80 \%$ of the sugars of must, being T19-3FS, T193-MS, T19-1FS the most similar in fermentation performance to the control strain. This suggests that these yeast strains could be used as a pure culture in the fermentation of high alcohol beverages and NS non-fermentative yeast strains could be used as a co-culture in mixed fermentations with $S$. cerevisiae for the production of low alcohol wine. As would be expected, sugar utilization and ethanol production were positively correlated. A similar trend was observed for glycerol production where some strains (T19-3FS, T19-3MS, T19-1FS) were as efficient as the control strain using the same amount of total sugars. Additionally, non-fermenting strain T19-2FN showed lower consumption of total sugar but was more efficient at producing glycerol. The main component of volatile acidity is acetic acid, which confers a vinegary aroma and its maximum acceptable limit is $1.2 \mathrm{~g}$ 
$/ L$ (Vilela et al. 2018). Fortunately, none of the strains tested exceeded that concentration, indicating it can be used to produce wines with accurate volatile acidity. What is more, T19-6MN, T19-10MN, T19-1FN, and T19-10MS stand out which were not capable of producing acetic acid, suggesting that these strains can be suitable for sequential fermentations since they can consume sugars without producing volatile acidity.

\section{$\beta$-Glucosidase activity}

There are several reports of NS strains isolated from oenological environments that are producers of hydrolytic enzymatic activities of oenological interest, such as $\beta$-glucosidase (BGL) activity (Mateo et al. 2011; Zhang et al. 2020). These enzymes catalyze the hydrolysis of non-volatile glycosides, releasing the aromatic compounds, enhancing flavors and aromas (de Ovalle et al. 2018; González-Pombo et al. 2008). For both, filamentous fungi and yeasts, it has been reported that the production of BGL activity decreases at low pH (4.0) being optimal its production at pH values around 5.0-5.5 (de Ovalle et al. 2018; García-Kirchner et al. 2005; Javed et al. 2006). This constitutes a challenge in the search for new strains expressing this activity at low pH values. The screening of the native NS strains showed that, after $96 \mathrm{~h}$ of incubation at pH 4.0, BGL activity was observed as a brown halo around a streak in two isolates: Pichia terricola T19-1FN and Saturnispora diversa T19-1FS (Fig. 3), corresponding to $22 \%$ of all tested strains. Although there are several reports of screening BGL activity in EGA, almost inexistent report results at low acidic pH (Ortiz-Barrera et al. 2015). Pérez et al. (2011), reported the study of BGL production in 154 native yeast strains (NS and S) and observed that only $20 \%$ showed BGL activity at pH 6.0 and most of these $(70 \%)$ were NS strains. A similar result was observed by Strauss et al. (2001), for a collection of 245 NS strains of wine yeast at pH 5.0, BGL activity was observed only for 8 strains and with very poor production. Batra et al. (2014) studied the expression of $\mathrm{BGL}$ in P. pastoris in the range of $\mathrm{pH} 4.0$ to 8.0, observing the maximum expression at $\mathrm{pH} 7.5$, whereas the lowest activity was detected at $\mathrm{pH}$ 4.0. Concerning yeast species, our results are following previous findings, that $P$. terricola strains produce BGL activity at pH 4.0 (González-Pombo et al. 2011) and in the case of $S$. diversa, Maturano et al. (2009) did not find BGL activity in a qualitative test at pH 4.5 and 6.5 .

\section{Killer phenotype}

The use of compatible strains in appropriate proportions to avoid stuck wine fermentation is a key consideration. So, killer phenotype, resistance, and sensitivity to killer factors are important aspects to consider for the selection of yeast strains in winemaking (Maqueda et al. 2012). The analysis of the intensity of the killer activity allowed us to differentiate strains with high killer activity (+++), moderate killer activity (++), and low killer activity (+) (Table 5).

The majority of strains tested were killer and resistant (K+R): S. bacillaris T19-3MS, S. cerevisiae T19-3FS, $S$. diversa T19-1FS, P. terricola T19-1FN, P. occidentalis T19-2FN, M, peoriensis T19-6MN, and P. cfr. fermentans T19-10MN. Nevertheless, $H$. uvarum T19-2MN showed $\mathrm{K}+\mathrm{S}$ phenotype and M. pulcherrima T19$10 \mathrm{MS}$ was the only, not killer and sensitive (K-S). These findings are promising for winemaking as it is challenging to find K+R strains (Lopes and Sangorrín 2010).

\section{Table 5}

Page $10 / 24$ 


\section{Conclusions}

We investigated yeast diversity of yeasts associated with the emblematic variety of our country, Tannat from an avant-garde winery, Bodega Garzón. The strains were physiologically and biochemically characterized, such as resistance to antimicrobial compounds and ethanol, fermentation and growth kinetic, $\beta$-glucosidase activity, and killer factor, to identify strains suitable to improve local expression of the wines. S. cerevisiae T19-3FS, S. bacillaris T19-3MS, and S. diversa T19-1FS exhibited the best performance in the ethanol/SO2 challenge and sugar utilization and ethanol production were positively correlated highlighting its potential use in pure starter cultures for the production of finished wines. It also notes that $S$. diversa T191FS exhibits BGL activity making it interesting to explore its possible activity onto non-volatile glycosides during fermentation, to enhance aromatic compounds. In particular, considering the high BGL production at acidic $\mathrm{pH}$ of $P$. terricola T19-1FN and its inhibition in the presence of ethanol in concentrations greater than $6 \%$, it is a promising candidate to study its possible contribution to wine complexity in co-fermentations with $S$. cerevisiae strains. This results also suggest that the inoculation of must with new strains of $S$ and NS carefully selected, complemented with aromatic profile studies, constitute an important biotechnological tool to obtain local and distinctive wines. Furthermore, this would allow not only gathering the current challenge of the complexity of the quality of the wine but also obtain "wines with low alcohol content" for the adaptation to a changing market.

\section{Declarations}

Compliance with ethical standards This article does not contain any studies with human participants or animals performed by any of the authors. Informed consent was obtained from all individual participants included in the study.

Funding This study was funded by AGROLAND S.A. Company.

Competing interests Authors declare that they have no conflict of interest.

\section{References}

1. Baffi MA, Dos Santos Bezerra C, Arévalo-Villena M, Isabel Briones-Pérez A, Gomes E, Da Silva R (2011) Isolation and molecular identification of wine yeasts from a Brazilian vineyard. Ann Microbiol 61:7578. https://doi.org/10.1007/s13213-010-0099-z

2. Batra J, Beri D, Mishra S (2014) Response surface methodology based optimization of $\beta$-glucosidase production from Pichia pastoris. Appl Biochem Biotechnol 172:380-393. https://doi.org/10.1007/s12010-013-0519-1

3. Binati RL, Innocente G, Gatto V, Celebrin A, Polo M, Felis GE, Torriani S (2019) Exploring the diversity of a collection of native non-Saccharomyces yeasts to develop co-starter cultures for winemaking. Food Res Int 122:432-442. https://doi.org/10.1016/j.foodres.2019.04.043

4. Boido E, Lloret A, Medina K, Fariña L, Carrau F, Versini G, Dellacassa E (2003) Aroma composition of Vitis vinifera cv. Tannat: The typical red wine from Uruguay. J Agric Food Chem 51:5408-5413. 
https://doi.org/10.1021/jf030087i

5. Bougreau M, Ascencio K, Bugarel M, Nightingale K, Loneragan G (2019) Yeast species isolated from Texas High Plains vineyards and dynamics during spontaneous ferme of Tempranillo grapes. PLoS ONE 14:1-15. https://doi.org/10.1371/journal.pone.0216246

6. Capece A, Granchi L, Guerrini S, Mangani S, Romaniello R, Vincenzini M, Romano P (2016) Diversity of Saccharomyces cerevisiae strains isolated from two Italian wine-producing regions. Front Microbiol 7:1-11. https://doi.org/10.3389/fmicb.2016.01018

7. Cappello MS, Bleve G, Grieco F, Dellaglio F, Zacheo G (2004) Characterization of Saccharomyces cerevisiae strains isolated from must of grape grown in the experimental vineyard. J Appl Microbiol 97:1274-1280. https://doi.org/10.1111/j.1365-2672.2004.02412.x

8. Castilleja DEM, Tapia JAA, Medrano SMA, Iturriaga MH, Muñoz LS, Peniche RÁM (2017) Growth Kinetics for the Selection of Yeast Strains for Fermented Beverages. In: Yeast - Industrial Applications, IntechOpen, London, UK, pp 67-87

9. Chavan P, Mane S, Kulkarni G, Shaikh S, Ghormade V, Nerkar DP, Shouche Y, Deshpande MV (2009) Natural yeast flora of different varieties of grapes used for wine making in India. Food Microbiol 26:801-808. https://doi.org/10.1016/j.fm.2009.05.005

10. Ciani M, Comitini F (2015) Yeast interactions in multi-starter wine fermentation. Curr Opin Food Sci 1:16

11. Cordero-Bueso G, Esteve-Zarzoso B, Cabellos JM, Gil-Díaz M, Arroyo T (2013) Biotechnological potential of non-Saccharomyces yeasts isolated during spontaneous ferementations of Malvar (Vitis vinifera cv.

L.). Eur. Food Res Technol 236:193-207. https://doi.org/10.1007/s00217-012-1874-9

12. Corte L, Roscini L, Zadra C, Antonielli L, Tancini B, Magini A, Emiliani C, Cardinali G (2012) Effect of pH on potassium metabisulphite biocidic activity against yeast and human cell cultures. Food Chem 134:1327-1336. https://doi.org/10.1016/j.foodchem.2012.03.025

13. de Ovalle S, Cavello I, Brena BM, Cavalitto S, González-Pombo P (2018) Production and characterization of a $\beta$-glucosidase from Issatchenkia terricola and its use for hydrolysis of aromatic precursors in Cabernet Sauvignon wine. LWT - Food Sci Technol 87:515-522.

https://doi.org/10.1016/j.Iwt.2017.09.026

14. Di Rienzo JA, Macchiavelli R, Casanoves F (2017) Mixed models in Infostat, Repositorio CATIE. https://repositorio.bibliotecaorton.catie.ac.cr/bitstream/handle/11554/8691/Linear_mixed_models.pdf. Accessed Jun 2017

15. Eder MLR, Reynoso C, Lauret SC, Rosa AL (2017) Isolation and Identification of the Indigenous Yeast Population during Spontaneous Fermentation of Isabella (Vitis labrusca L.) Grape Must. Front Microbiol 8:1-8. https://doi.org/10.3389/fmicb.2017.00532

16. Englezos V, Rantsiou K, Torchio F, Rolle L, Gerbi V, Cocolin L (2015) Exploitation of the nonSaccharomyces yeast Starmerella bacillaris (synonym Candida zemplinina) in wine fermentation: Physiological and molecular characterizations. Int J Food Microbiol 199:33-40. https://doi.org/10.1016/j.jifoodmicro.2015.01.009 
17. Fariña L, Villar V, Ares G, Carrau F, Dellacassa E, Boido E (2015) Volatile composition and aroma profile of Uruguayan Tannat wines. FRIN 69:244-255. https://doi.org/10.1016/j.foodres.2014.12.029

18. Flakus A, Etayo J, Miadlikowska J, Lutzoni F, Kukwa M, Matura N, Rodriguez-Flakus P (2019) Biodiversity assessment of ascomycetes inhabiting Lobariella lichens in Andean cloud forests led to one new family, three new genera and 13 new species of lichenicolous fungi. Plant Fungal Syst 64:283-344. https://doi.org/10.2478/pfs-2019-0022

19. Francesca N, Chiurazzi M, Romano R, Aponte M, Settanni L, Moschetti G (2010) Indigenous yeast communities in the environment of "Rovello bianco" grape variety and their use in commercial white wine fermentation. World J Microbiol Biotechnol 26:337-351. https://doi.org/10.1007/s11274-0090181-5

20. García-Kirchner O, Segura-Granados M, Rodríguez-Pascual P (2005) Effect of media composition and growth conditions on production of $\beta$-glucosidase by Aspergillus niger C-6. Appl Biochem Biotechnol Part A Enzym Eng Biotechnol 121:347-359. https://doi.org/10.1007/978-1-59259-991-2_30

21. González-Pombo P, Fariña L, Carrau F, Batista-Viera F, Brena B (2011) A novel extracellular $\beta$ glucosidase from Issatchenkia terricola: Isolation, immobilization and application for aroma enhancement of white Muscat wine. Process Biochem 46:385-389. https://doi.org/10.1016/j.procbio.2010.07.016

22. González-Pombo P, Pérez G, Carrau F, Guisán JM, Batista-Viera F, Brena BM (2008) One-step purification and characterization of an intracellular $\beta$-glucosidase from Metschnikowia pulcherrima. Biotechnol Lett 30:1469-1475. https://doi.org/10.1007/s10529-008-9708-3

23. Hong YA, Park HD (2013) Role of non-Saccharomyces yeasts in Korean wines produced from Campbell Early grapes: Potential use of Hanseniaspora uvarum as a starter culture. Food Microbiol 34:207-214. https://doi.org/10.1016/j.fm.2012.12.011

24. Javed MM, Siddiq Z, Saleem T (2006) Triggering of $\beta$-glucosidase Production in Trichoderma viride with Nutritional and Environmental Control. Res J Appl Sci 2:884-889

25. Jolly NP, Augustyn OPH, Pretorius IS (2006) The Role and Use of Non-Saccharomyces Yeasts in Wine Production. S Afr J Enol Vitic 27:15-39

26. Jolly NP, Varela C, Pretorius IS (2014) Not your ordinary yeast: Non-Saccharomyces yeasts in wine production uncovered. FEMS Yeast Res 14:215-237. https://doi.org/10.1111/1567-1364.12111

27. Lopes CA, Sangorrín MP (2010) Optimization of killer assays for yeast selection protocols. Rev Argent Microbiol 42:298-306. https://doi.org/10.1590/S0325-75412010000400011

28. Lopez MC, Mateo JJ, Maicas S (2015) Screening of $\beta$-Glucosidase and $\beta$-Xylosidase Activities in Four Non- Saccharomyces Yeast Isolates. J Food Sci 80:C1696-C1704. https://doi.org/10.1111/17503841.12954

29. Madigan MT, Martinko JM (2006) Brock Biology of Microorganisms, eleventh ed. Prentice Hall, Upper Saddle River, NJ, USA

30. Maio D, Polizzotto G, Planeta D, Oliva D (2012) A method to discriminate between the Candida stellata and Saccharomyces cerevisiae in mixed fermentation on WLD and lysine agar media. South Afr J Enol Vitic 32:35-41. https://doi.org/10.21548/33-1-1316 
31. Maqueda M, Zamora E, Álvarez ML, Ramírez M (2012) Characterization, ecological distribution, and population dynamics of Saccharomyces sensu stricto Killer yeasts in the spontaneous grape must fermentations of Southwestern Spain. Appl Environ Microbiol 78:735-743. https://doi.org/10.1128/AEM.06518-11

32. Maro ED, Ercolini D, Coppola S (2007) Yeast dynamics during spontaneous wine fermentation of the Catalanesca grape. Int J Food Microbiol 117:201-210.

https://doi.org/10.1016/j.jfoodmicro.2007.04.007

33. Mateo JJ, Peris L, Ibañez C, Maicas S (2011) Characterization of glycolytic activities from nonSaccharomyces yeasts isolated from Bobal musts. J Ind Microbiol Biotechnol 38:347-354. https://doi.org/10.1007/s10295-010-0780-z

34. Maturano YP, Nally MC, Toro ME, Castellanos de Figueroa L, Vazquez F (2009) Estudio cualitativo de actividades enzimáticas y fenómeno killer en levaduras vínicas. Revista de Enología 1:1-11

35. Nasanit R, Jaibangyang S, Tantirungkij M, Limtong S (2016) Yeast diversity and novel yeast D1/D2 sequences from corn phylloplane obtained by a culture-independent approach. Antonie van Leeuwenhoek Int J Gen Mol Microbiol 109:1615-1634. https://doi.org/10.1007/s10482-016-0762-x

36. Ortiz-Barrera E, Miranda-Castilleja DE, Arvizu-Medrano SM, Pacheco-Aguilar JR, Aldrete-Tapia JA, Hernandez-Iturriaga M, Martinez-Peniche RA (2015) Potencial enológico de levaduras noSaccharomyces nativas de Viñedos establecidos en Querétaro. México Rev Chapingo Ser Hortic 21:169-183. https://doi.org/10.5154/r.rchsh.2015.01.001

37. Padilla B, Gil JV, Manzanares P (2016) Past and Future of Non-Saccharomyces Yeasts: From Spoilage Microorganisms to Biotechnological Tools for Improving Wine Aroma Complexity. Front Microbiol. doi: 10.3389/fmicb.2016.00411

38. Pallmann CL, Brown JA, Olineka TL, Cocolin L, Mills DA, Bisson LF (2001) Use of WL medium to profile native flora fermentations. Am J Enol Vitic 52:198-203

39. Pérez G, Fariña L, Barquet M, Boido E, Gaggero C, Dellacassa E, Carrau F (2011) A quick screening method to identify $\beta$-glucosidase activity in native wine yeast strains: Application of Esculin Glycerol Agar (EGA) medium. World J Microbiol Biotechnol 27:47-55. https://doi.org/10.1007/s11274-0100425-4

40. Pina C, Santos C, Couto JA, Hogg T (2004) Ethanol tolerance of five non-Saccharomyces wine yeasts in comparison with a strain of Saccharomyces cerevisiae - Influence of different culture conditions. Food Microbiol 21:439-447. https://doi.org/10.1016/j.fm.2003.10.009

41. Puig S, Ramón D, Pérez-Ortín JE (1998) Optimized Method To Obtain Stable Food-Safe Recombinant Wine Yeast Strains. J Agric Food Chem 8561:1689-1693

42. Rainieri S, Pretorius IS (2000) Selection and improvement of wine yeasts. Ann Microbiol 50:15-31

43. Rojo-Bezares B, Sáenz Y, Navarro L, Zarazaga M, Ruiz-Larrea F, Torres C (2007) Coculture-inducible bacteriocin activity of Lactobacillus plantarum strain $\mathrm{J} 23$ isolated from grape must. Food Microbiol 24:482-491. https://doi.org/10.1016/j.fm.2006.09.003

44. Romancino DP, Di Maio S, Muriella R, Oliva D (2008) Analysis of non-Saccharomyces yeast populations isolated from grape musts from Sicily (Italy). J Appl Microbiol 105:2248-2254. 
https://doi.org/10.1111/j.1365-2672.2008.03894.x

45. Sabate J, Cano J, Esteve-Zarzoso B, Guillamón JM (2002) Isolation and identification of yeasts associated with vineyard and winery by RFLP analysis of ribosomal genes and mitochondrial DNA. Microbiol Res 157:267-274. https://doi.org/10.1078/0944-5013-00163

46. Sadoudi M, Tourdot-Maréchal R, Rousseaux S, Steyer D, Gallardo-Chacón JJ, Ballester J, Vichi S, GuérinSchneider R, Caixach J, Alexandre H (2012) Yeast-yeast interactions revealed by aromatic profile analysis of Sauvignon Blanc wine fermented by single or co-culture of non-Saccharomyces and Saccharomyces yeasts. Food Microbiol 32:243-253. https://doi.org/10.1016/j.fm.2012.06.006

47. Senses-Ergul S, Ozbas ZY (2016) Characterization of some indigenous Saccharomyces cerevisiae isolates obtained during vinification of "kalecik karasi" and "emir" grapes grown in central Anatolia. Cienc e Tec Vitivinic 31:51-62. https://doi.org/10.1051/ctv/20163102051

48. Silva S, Negri M, Henriques M, Oliveira R, Williams DW, Azeredo J (2012) Candida glabrata, Candida parapsilosis and Candida tropicalis: Biology, epidemiology, pathogenicity and antifungal resistance. FEMS Microbiol Rev 36:288-305. https://doi.org/10.1111/j.1574-6976.2011.00278.x

49. Strauss MLA, Jolly NP, Lambrechts MG, Rensburg PV (2001) Screening for the production of extracellular hydrolytic enzymes by non-Saccharomyces wine yeasts. J Appl Microbiol 91:182-190

50. Suárez-Lepe JA, Morata A (2012) New trends in yeast selection for winemaking. Trends Food Sci Technol 23:39-50

51. Šuranská H, Vránová D, Omelková J (2016) Isolation, identification and characterization of regional indigenous Saccharomyces cerevisiae strains. Brazilian J Microbiol 47:181-190. https://doi.org/10.1016/j.bjm.2015.11.010

52. Tikka C, Osuru HP, Atluri N, Raghavulu P, yellapu NK, Mannur IS, Prasad UV, Aluru S, Varma KN, Bhaskar $M(2013)$ Isolation and characterization of ethanol tolerant yeast strains. Bioinformation 9:421-425. https://doi.org/10.6026/97320630009421

53. Tofalo R, Schirone M, Telera GC, Manetta AC, Corsetti A, Suzzi G (2011) Influence of organic viticulture on non-Saccharomyces wine yeast populations. Ann Microbiol 61:57-66. https://doi.org/10.1007/s13213-010-0102-8

54. Vilela A (2018) Lachancea thermotolerans, the Non-Saccharomyces yeast that reduces the volatile acidity of wines. Fermentation. doi:10.3390/fermentation4030056

55. Vigentini I, Cardenas SB, Valdetara F, Faccincani M, Panont CA, Picozzi C, Foschino R (2017) Use of native yeast strains for in-bottle fermentation to face the uniformity in sparkling wine production. Front Microbiol 8:1-10. https://doi.org/10.3389/fmicb.2017.01225

56. Wu ZW, Wang QM, Liu XZ, Bai FY (2016) Intragenomic polymorphism and intergenomic recombination in the ribosomal RNA genes of strains belonging to a yeast species Pichia membranifaciens. Mycology 7:102-111. https://doi.org/10.1080/21501203.2016.1204369

57. Zhang W, Zhuo X, Hu L, Zhang X (2020) Effects of crude $\beta$-glucosidases from Issatchenkia terricola, Pichia kudriavzevii, Metschnikowia pulcherrima on the flavor complexity and characteristics of wines. Microorganisms 8:1-16. https://doi.org/10.3390/microorganisms8060953 
58. Zott K, Miot-Sertier C, Claisse O, Lonvaud-Funel A, Masneuf-Pomarede I (2008) Dynamics and diversity of non- Saccharomyces yeasts during the early stages in winemaking. Int J Food Microbiol 125:197203. https://doi.org/10.1016/j.jffoodmicro.2008.04.001

59. Zuzuarregui A, del Olmo M (2004) Analyses of stress resistance under laboratory conditions constitute a suitable criterion for wine yeast selection. Antonie van Leeuwenhoek. Int J Gen Mol Microbiol 85:271280. https://doi.org/10.1023/B:ANT0.0000020162.21248.53

\section{Tables}


Table 1

Species and morphological characterization of native isolated yeasts.

\begin{tabular}{|c|c|c|c|}
\hline Species & Color & $\begin{array}{l}\text { Topography (Aspect, size and } \\
\text { elevation) }\end{array}$ & $\begin{array}{l}\text { Microscopy } \\
\text { shape }\end{array}$ \\
\hline $\begin{array}{l}\text { Aureobasidium } \\
\text { pullulans }\end{array}$ & Yellow to green with dark center & $\begin{array}{l}\text { Smooth, dull to shiny, medium } \\
\text { size, convex }\end{array}$ & $\begin{array}{l}\text { Ovoid, lemon } \\
\text { shape }\end{array}$ \\
\hline $\begin{array}{l}\text { Candida } \\
\text { parapsilosis }\end{array}$ & Blue to deep green & $\begin{array}{l}\text { Smooth to rough, dull to shiny, } \\
\text { small, convex }\end{array}$ & Globose \\
\hline $\begin{array}{l}\text { Filobasidium } \\
\text { magnum }\end{array}$ & Green center with white halo & $\begin{array}{l}\text { Smooth, shiny, medium size, } \\
\text { convex }\end{array}$ & Globose \\
\hline $\begin{array}{l}\text { Hanseniaspora } \\
\text { uvarum }\end{array}$ & $\begin{array}{l}\text { Dark green, differentiated dark } \\
\text { center }\end{array}$ & Smooth, shiny, large, convex & Apiculate \\
\hline $\begin{array}{l}\text { Metschnikowia } \\
\text { peoriensis }\end{array}$ & Light blue, turquoise & $\begin{array}{l}\text { Smooth, dull, medium to large } \\
\text { size, convex }\end{array}$ & Globose \\
\hline $\begin{array}{l}\text { Metschnikowia } \\
\text { pulcherrima }\end{array}$ & $\begin{array}{l}\text { Greenish gray, reddish halo } \\
\text { (pulcherrimin) }\end{array}$ & $\begin{array}{l}\text { Smooth, shiny, small to } \\
\text { medium size, convex }\end{array}$ & $\begin{array}{l}\text { Globose to } \\
\text { ovoid }\end{array}$ \\
\hline $\begin{array}{l}\text { Papiliotrema } \\
\text { terrestris }\end{array}$ & Whitish with green center & $\begin{array}{l}\text { Smooth, shiny, little to medium } \\
\text { size, convex }\end{array}$ & $\begin{array}{l}\text { Slightly } \\
\text { globose }\end{array}$ \\
\hline $\begin{array}{l}\text { Pichia cfr. } \\
\text { fermentans }\end{array}$ & $\begin{array}{l}\text { Lime green to apple, } \\
\text { homogeneous }\end{array}$ & $\begin{array}{l}\text { Smooth, dull, small to medium } \\
\text { size, convex }\end{array}$ & $\begin{array}{l}\text { Globose to } \\
\text { slightly ovoid }\end{array}$ \\
\hline $\begin{array}{l}\text { Pichia } \\
\text { occidentalis }\end{array}$ & $\begin{array}{l}\text { Creamy white to greenish, } \\
\text { translucid outline }\end{array}$ & $\begin{array}{l}\text { Opaque, small to medium size, } \\
\text { convex }\end{array}$ & $\begin{array}{l}\text { Elongated } \\
\text { cells }\end{array}$ \\
\hline Pichia terricola & $\begin{array}{l}\text { Creamy white, with a greenish } \\
\text { center and translucid outline }\end{array}$ & $\begin{array}{l}\text { Smooth to rough, opaque, } \\
\text { medium size, flat to convex }\end{array}$ & $\begin{array}{l}\text { Ovoid to } \\
\text { cylindrical } \\
\text { cells }\end{array}$ \\
\hline $\begin{array}{l}\text { Rhodotorula } \\
\text { babjevae }\end{array}$ & Salmon, dark center & $\begin{array}{l}\text { Smooth, shiny, medium size, } \\
\text { convex }\end{array}$ & Ovoid \\
\hline $\begin{array}{l}\text { Saccharomyces } \\
\text { cerevisiae }\end{array}$ & Greenish cream & $\begin{array}{l}\text { Smooth, shiny, medium size, } \\
\text { convex, shaded }\end{array}$ & $\begin{array}{l}\text { Globose to } \\
\text { slightly ovoid }\end{array}$ \\
\hline $\begin{array}{l}\text { Saturnispora } \\
\text { diversa }\end{array}$ & Dark green, solid, homogeneous & $\begin{array}{l}\text { Smooth, shiny, medium size, } \\
\text { convex }\end{array}$ & Ovoid \\
\hline $\begin{array}{l}\text { Sporidiobolus } \\
\text { pararoseus }\end{array}$ & Pink, greenish center & $\begin{array}{l}\text { Rough, shiny, small to medium } \\
\text { size, slightly convex }\end{array}$ & $\begin{array}{l}\text { Ovoid to } \\
\text { elongate }\end{array}$ \\
\hline $\begin{array}{l}\text { Starmerella } \\
\text { bacillaris }\end{array}$ & $\begin{array}{l}\text { Dark green to apple, } \\
\text { homogeneous, whitish outline }\end{array}$ & $\begin{array}{l}\text { Smooth, shiny, small to } \\
\text { medium size, convex }\end{array}$ & $\begin{array}{l}\text { Slightly } \\
\text { globose to } \\
\text { ovoid }\end{array}$ \\
\hline
\end{tabular}


Table 2

Growth rate $(\mu)$ and length of lag phase for native yeasts in presence of ethanol or SO2 at $25^{\circ} \mathrm{C}$ and $\mathrm{pH} 3.5$.

\begin{tabular}{|c|c|c|c|c|c|c|c|c|}
\hline Strain & $6 \% \mathrm{v} /$ & TOH & $11 \%$ & $\mathrm{TOH}$ & $16 \%$ & $\mathrm{ETOH}$ & $40 \mathrm{~ms}$ & $\mathrm{SO}_{2}$ \\
\hline & $\begin{array}{l}\mu\left(\mathrm{h}^{-}\right. \\
\left.{ }^{1}\right)\end{array}$ & $\begin{array}{l}\text { Lag } \\
\text { phase } \\
\text { (h) }\end{array}$ & $\begin{array}{l}\mu\left(h^{-}\right. \\
\left.{ }^{1}\right)\end{array}$ & $\begin{array}{l}\text { Lag } \\
\text { phase } \\
\text { (h) }\end{array}$ & $\begin{array}{l}\mu\left(h^{-}\right. \\
\left.{ }^{1}\right)\end{array}$ & $\begin{array}{l}\text { Lag } \\
\text { phase } \\
\text { (h) }\end{array}$ & $\begin{array}{l}\mu\left(h^{-}\right. \\
\left.{ }^{1}\right)\end{array}$ & \\
\hline
\end{tabular}

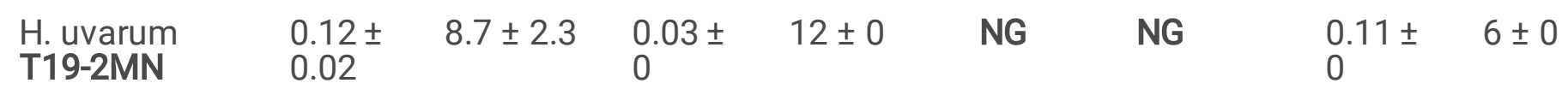

$\begin{array}{llllllll}\text { M. peoriensis } & 0.07 \pm & 11.3 \pm & 0.02 \pm & 12 \pm 0 \\ & 0.01 & 1.2 & 0 & \text { NG } & \text { NG } & \begin{array}{l}0.10 \pm \\ 0\end{array} & 4 \pm 0\end{array}$

T19-6MN

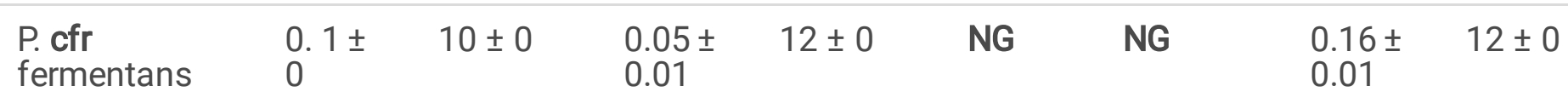

T19-10MN

\begin{tabular}{lllllllll} 
P. terricola & $0.13 \pm$ & $6 \pm 0$ & $0.05 \pm$ & $12 \pm 0$ & NG & NG & $\begin{array}{l}0.12 \pm \\
0.1\end{array}$ & $10 \pm 0$ \\
\hline & 0 & & 0.02
\end{tabular}

T19-1FN

$\begin{array}{lllllllll}\text { P. occidentalis } & 0.09 \pm & 6 \pm 0 & 0.07 \pm & 12 \pm 0 & \text { NG } & \text { NG } & \begin{array}{l}0.09 \pm \\ 0.02\end{array} & 0.7 \pm 1.2 \\ & 0.02\end{array}$

T19-2FN

$\begin{array}{lllllllll}\text { S. bacillaris } & 0.11 \pm & 6 \pm 0 & 0.09 \pm & 11.3 \pm & 0.06 \pm & 12 \pm 0 & 0.23 \pm & 4 \pm 0 \\ & 0.01 & & 0 & 1.2 & 0.03 & & 0,01 & \end{array}$

T19-3MS

$\begin{array}{lllllllll}\text { M. } & 0.1 \pm & 12 \pm 0 & 0.03 \pm & 12 \pm 0 & \text { NG } & \text { NG } & 0.11 \pm & 10 \pm 0 \\ \text { pulcherrima } & 0.01 & & 0.01\end{array}$

T19-10MS

\begin{tabular}{|c|c|c|c|c|c|c|c|c|}
\hline $\begin{array}{l}\text { S. diversa } \\
\text { T19-1FS }\end{array}$ & $\begin{array}{l}0.11 \pm \\
0\end{array}$ & $6 \pm 0$ & $\begin{array}{l}0.07 \pm \\
0.02\end{array}$ & $12 \pm 0$ & NG & NG & $\begin{array}{l}0.11 \pm \\
0\end{array}$ & $4 \pm 0$ \\
\hline $\begin{array}{l}\text { S. cerevisiae } \\
\text { T19-3FS }\end{array}$ & $\begin{array}{l}0.19 \pm \\
0.01\end{array}$ & $2 \pm 0$ & $\begin{array}{l}0.15 \pm \\
0.05\end{array}$ & $4 \pm 0$ & $0.1 \pm 0$ & $4 \pm 0$ & $\begin{array}{l}0.25 \pm \\
0,01\end{array}$ & $2 \pm 0$ \\
\hline $\begin{array}{l}\text { S. cerevisiae } \\
\text { T73-2 }\end{array}$ & $\begin{array}{l}0.2 \pm \\
0.01\end{array}$ & $2 \pm 0$ & $\begin{array}{l}0.17 \pm \\
0.06\end{array}$ & $4 \pm 0$ & $\begin{array}{l}0.17 \pm \\
0.06\end{array}$ & $4 \pm 0$ & $\begin{array}{l}0.26 \pm \\
0.02\end{array}$ & $2 \pm 0$ \\
\hline
\end{tabular}

NG: not growth 
Table 3

Inhibition percentage of native yeasts in presence of ethanol or SO2.

\begin{tabular}{|c|c|c|c|c|}
\hline \multirow[t]{2}{*}{ Strain } & \multicolumn{4}{|c|}{$\%$ Inhibition } \\
\hline & $6 \%$ ETOH & $11 \%$ ETOH & $16 \%$ ETOH & $\mathrm{SO}_{2} 40 \mathrm{mg} / \mathrm{L}$ \\
\hline H. uvarum & $17 \pm 6$ & $79 \pm 3$ & $88 \pm 0$ & $15 \pm 5$ \\
\hline \multicolumn{5}{|l|}{ T19-2MN } \\
\hline M. peoriensis & $60 \pm 6$ & $81 \pm 4$ & $87 \pm 2$ & $2 \pm 4$ \\
\hline \multicolumn{5}{|l|}{ T19-6MN } \\
\hline P. cfr. fermentans & $18 \pm 14$ & $72 \pm 4$ & $95 \pm 1$ & $8 \pm 4$ \\
\hline \multicolumn{5}{|l|}{ T19-10MN } \\
\hline P. terricola & $2 \pm 2$ & $76 \pm 12$ & $95 \pm 1$ & $2 \pm 3$ \\
\hline \multicolumn{5}{|l|}{ T19-1FN } \\
\hline P. occidentalis & $15 \pm 3$ & $55 \pm 10$ & $87 \pm 1$ & $3 \pm 3$ \\
\hline \multicolumn{5}{|l|}{ T19-2FN } \\
\hline S. bacillaris & N.D. & $22 \pm 8$ & $83 \pm 6$ & $7 \pm 3$ \\
\hline \multicolumn{5}{|l|}{ T19-3MS } \\
\hline M. pulcherrima & $39 \pm 6$ & $78 \pm 6$ & $90 \pm 2$ & $11 \pm 0$ \\
\hline \multicolumn{5}{|l|}{ T19-10MS } \\
\hline S. diversa & $6 \pm 1$ & $62 \pm 19$ & $93 \pm 1$ & $0 \pm 1$ \\
\hline \multicolumn{5}{|l|}{ T19-1FS } \\
\hline S. cerevisiae T19-3FS & ND & ND & ND & ND \\
\hline S. cerevisiae T73-2 & ND & ND & ND & $6 \pm 5$ \\
\hline
\end{tabular}


Table 4

Concentration of residual sugars (glucose, fructose) and fermentation metabolites (glycerol, acetic acid and ethanol) reached by selected strains, at the end of Tannat must fermentation

\begin{tabular}{|c|c|c|c|c|c|}
\hline & $\begin{array}{l}\text { Glucose } \\
\text { [g/L] }\end{array}$ & $\begin{array}{l}\text { Fructose } \\
\text { [g/L] }\end{array}$ & $\begin{array}{l}\text { Glycerol } \\
\text { [g/L] }\end{array}$ & $\begin{array}{l}\text { Acetic acid } \\
{[\mathrm{g} / \mathrm{L}]}\end{array}$ & $\begin{array}{l}\text { Ethanol } \\
\text { [\% v/v] }\end{array}$ \\
\hline H. uvarum T19-2MN ** & $\begin{array}{l}13.03( \pm \\
8.67)\end{array}$ & $\begin{array}{l}16.96( \pm \\
4.16)\end{array}$ & $\begin{array}{l}8.34( \pm \\
0.63)\end{array}$ & $0.46( \pm 0.11)$ & $\begin{array}{l}8.20( \pm \\
2.41)\end{array}$ \\
\hline M. peoriensis T19-6MN* & $\begin{array}{l}26.50( \pm \\
1.47)\end{array}$ & $\begin{array}{l}39.97( \pm \\
2.46)\end{array}$ & $\begin{array}{l}9.57( \pm \\
0.88)\end{array}$ & $0.00( \pm 0.00)$ & $\begin{array}{l}6.27( \pm \\
0.30)\end{array}$ \\
\hline $\begin{array}{l}\text { P. cfr. Fermentans T19- } \\
\text { 10MN* }\end{array}$ & $\begin{array}{l}18.66( \pm \\
2.52)\end{array}$ & $\begin{array}{l}54.67( \pm \\
6.96)\end{array}$ & $\begin{array}{l}7.63( \pm \\
0.05)\end{array}$ & $0.00( \pm 0.00)$ & $\begin{array}{l}4.59( \pm \\
0.34)\end{array}$ \\
\hline P. terricola T19-1FN* & $\begin{array}{l}21.84( \pm \\
1.86)\end{array}$ & $\begin{array}{l}78.90( \pm \\
3.35)\end{array}$ & $\begin{array}{l}8.49( \pm \\
0.64)\end{array}$ & $0.00( \pm 0.00)$ & $\begin{array}{l}4.71( \pm \\
0.63)\end{array}$ \\
\hline P. occidentalis T19-2FN* & $\begin{array}{l}6.97( \pm \\
1.12)\end{array}$ & $\begin{array}{l}51.11( \pm \\
3.27)\end{array}$ & $\begin{array}{l}14.84( \pm \\
1.25)\end{array}$ & $0.11( \pm 0.17)$ & $\begin{array}{l}7.07( \pm \\
0.63)\end{array}$ \\
\hline S. bacillaris T19-3MS** & $\begin{array}{l}1.38( \pm \\
0.14)\end{array}$ & $\begin{array}{l}1.01( \pm \\
0.05)\end{array}$ & $\begin{array}{l}17.33( \pm \\
2.09)\end{array}$ & $0.57( \pm 0.13)$ & $\begin{array}{l}11.07( \pm \\
0.41)\end{array}$ \\
\hline $\begin{array}{l}\text { M. pulcherrima T19- } \\
\text { 10MS* }\end{array}$ & $\begin{array}{l}13.29( \pm \\
1.71)\end{array}$ & $\begin{array}{l}53.37( \pm \\
4.44)\end{array}$ & $\begin{array}{l}8.13( \pm \\
0.46)\end{array}$ & $0.00( \pm 0.00)$ & $\begin{array}{l}6.54( \pm \\
0.51)\end{array}$ \\
\hline S. diversa T19-1FS** & $\begin{array}{l}4.91( \pm \\
0.96)\end{array}$ & $\begin{array}{l}1.82( \pm \\
1.36)\end{array}$ & $\begin{array}{l}15.52( \pm \\
1.64)\end{array}$ & $0.76( \pm 0.23)$ & $\begin{array}{l}10.84( \pm \\
0.84)\end{array}$ \\
\hline S. cerevisiae T19-3FS** & $\begin{array}{l}1.10( \pm \\
0.05)\end{array}$ & $\begin{array}{l}1.41( \pm \\
0.33)\end{array}$ & $\begin{array}{l}14.69( \pm \\
1.42)\end{array}$ & $0.31( \pm 0.21)$ & $\begin{array}{l}10.69( \pm \\
0.67)\end{array}$ \\
\hline S. cerevisiae T73-2** & $\begin{array}{l}1.16( \pm \\
0.05)\end{array}$ & $\begin{array}{l}1.72( \pm \\
0.23)\end{array}$ & $\begin{array}{l}13.27( \pm \\
0.35)\end{array}$ & $0.46( \pm 0.12)$ & $\begin{array}{l}11.08( \pm \\
0.02)\end{array}$ \\
\hline
\end{tabular}


Table 5

Intensity of the killer activity and phenotype

\begin{tabular}{|lll|}
\hline Strain & Killer activity & Killer phenotype \\
H. uvarum & ++ & $\mathrm{K}+/ \mathrm{S}$ \\
T19-2MN & & \\
M. peoriensis & ++ & $\mathrm{K}+/ \mathrm{R}$ \\
T19-6MN & & \\
\hline P. cfr. fermentans & + & $\mathrm{K}+/ \mathrm{R}$ \\
T19-10MN & & \\
\hline $\begin{array}{l}\text { P. terricola } \\
\text { T19-1FN }\end{array}$ & ++ & $\mathrm{K}+/ \mathrm{R}$ \\
\hline P. occidentalis & ++ & $\mathrm{K}+/ \mathrm{R}$ \\
T19-2FN & & \\
\hline S. bacillaris & + & $\mathrm{K}+/ \mathrm{R}$ \\
T19-3MS & & $\mathrm{K}-/ \mathrm{S}$ \\
\hline M. pulcherrima & $\mathrm{N} . \mathrm{D}$. & \\
T19-10MS & & $\mathrm{K}+/ \mathrm{R}$ \\
\hline $\begin{array}{l}\text { S. diversa } \\
\text { T19-1FS }\end{array}$ & ++ & \\
\hline $\begin{array}{l}\text { S. cerevisiae } \\
\text { T19-3FS }\end{array}$ & +++ & \\
\hline
\end{tabular}

Figures 


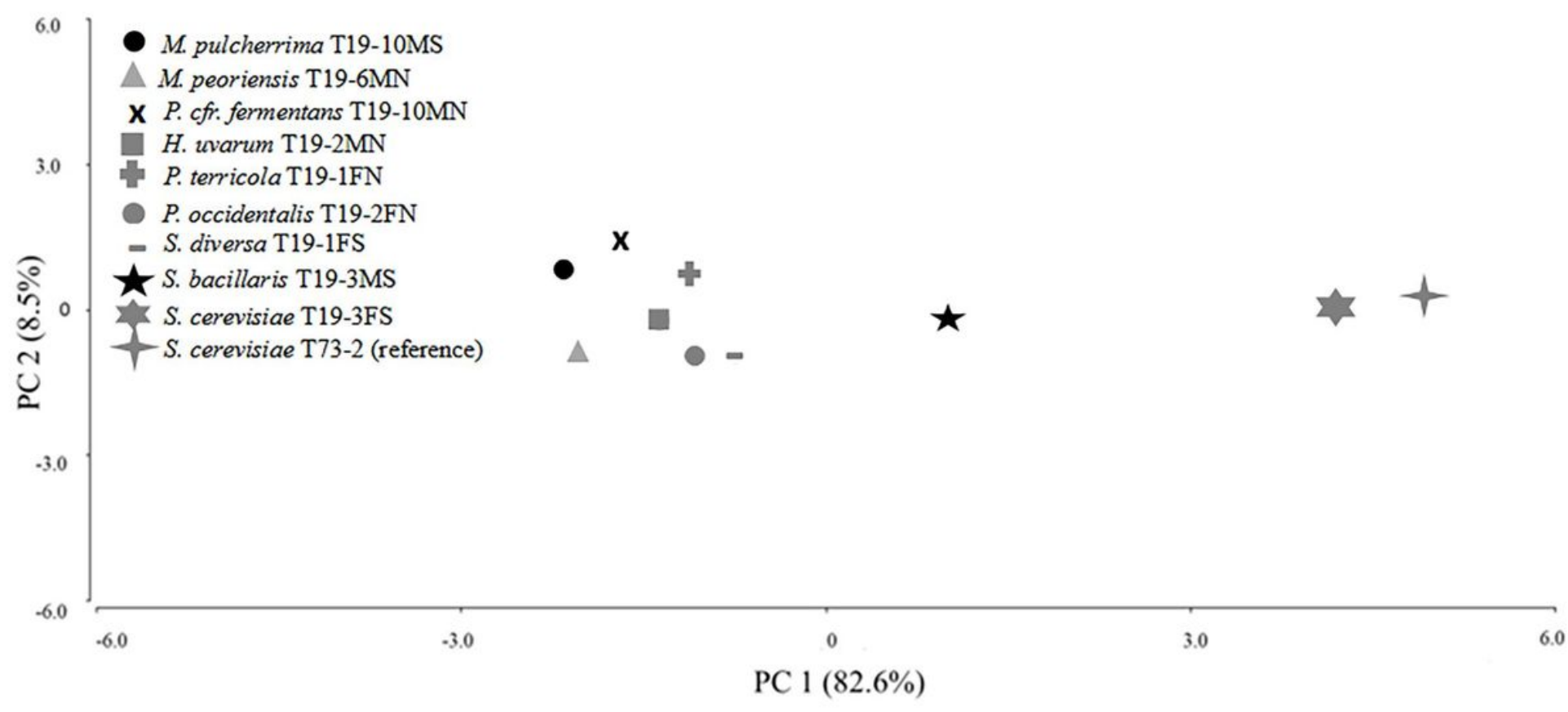

\section{Figure 1}

Principal Component Analysis of the growth rate $(\mu)$ and length of lag phase for native yeasts in presence of ethanol $/ \mathrm{SO}_{2}$ at $25^{\circ} \mathrm{C}$ and $\mathrm{pH} 3.5$. 


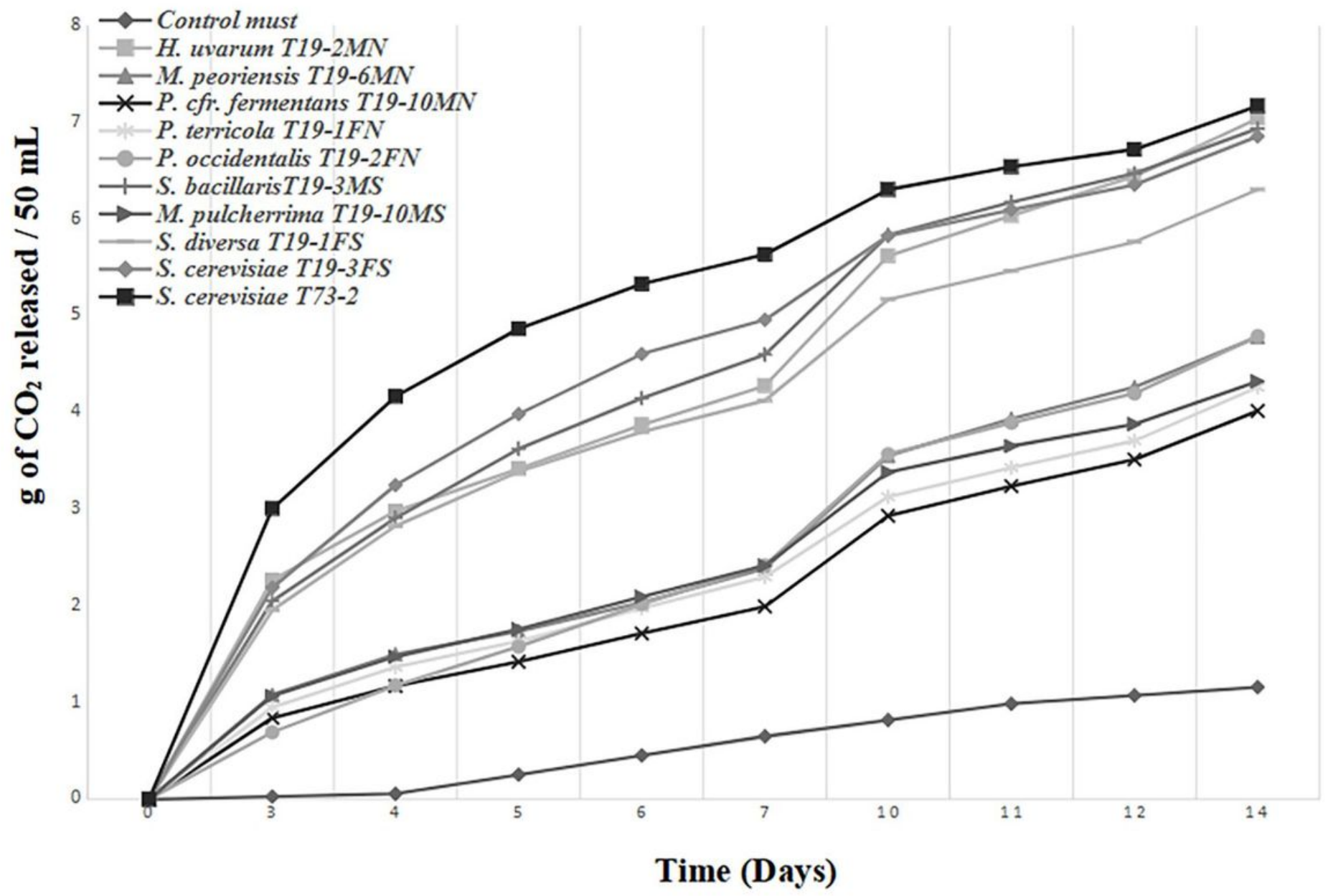

Figure 2

Release of $\mathrm{CO}_{2}$ during fermentation of Tannat must with selected native yeast strains. 


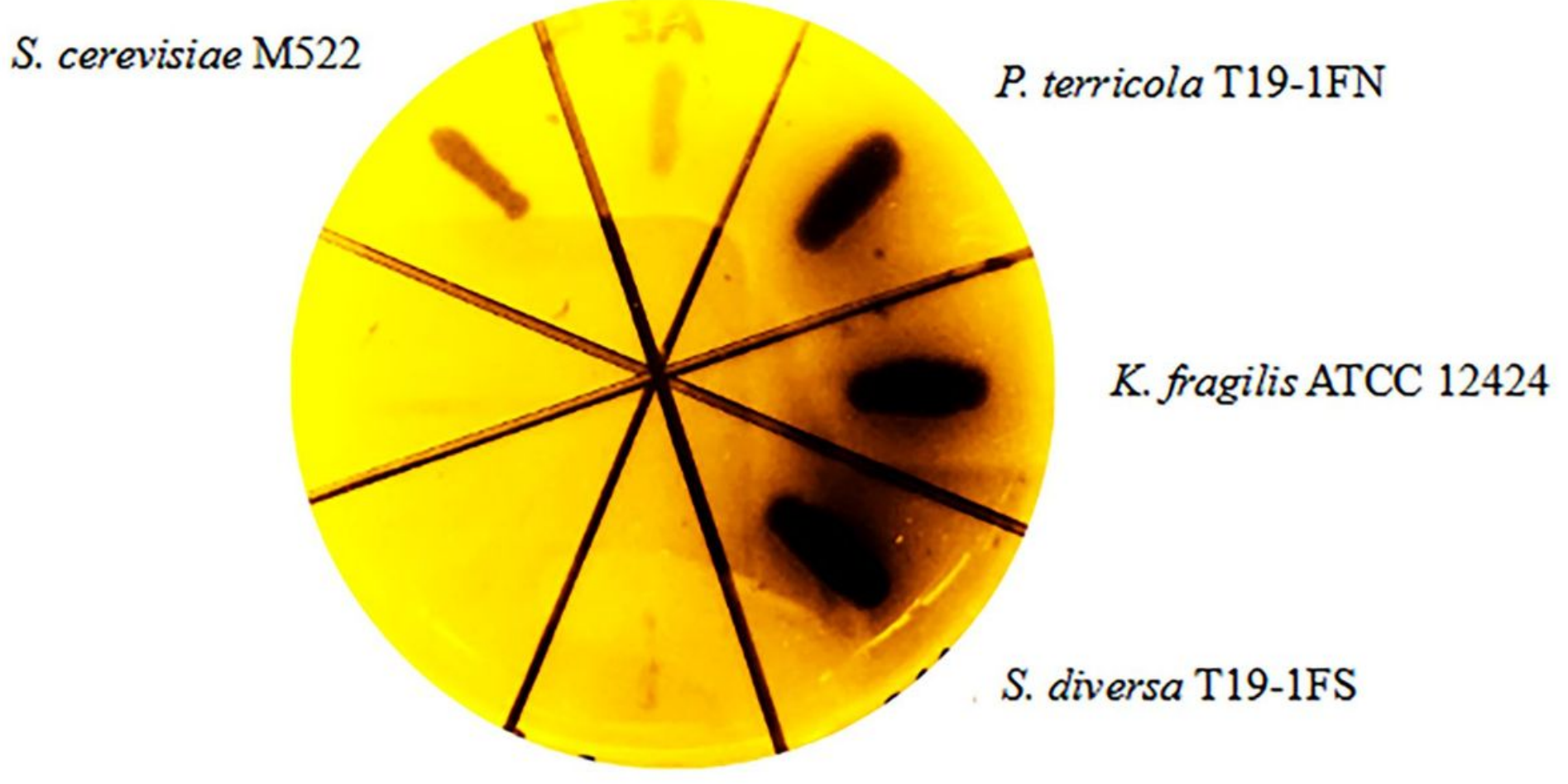

Figure 3

Screening for $\beta$-glucosidase activity on EGA medium at $\mathrm{pH}$ 4.0. S. cerevisiae M522 and $K$. fragilis ATCC12424 were used as the negative and positive control, respectively. 